University of Michigan Law School

University of Michigan Law School Scholarship Repository

Articles

Faculty Scholarship

1907

\title{
What Is the Practice of Medicine?
}

Harry B. Hutchins

University of Michigan Law School

Available at: https://repository.law.umich.edu/articles/1039

Follow this and additional works at: https://repository.law.umich.edu/articles

Part of the Medical Jurisprudence Commons

\section{Recommended Citation}

Hutchins, Harry B. "What Is the Practice of Medicine?" Mich. L. Rev. 4 (1906): 373-9.

This Article is brought to you for free and open access by the Faculty Scholarship at University of Michigan Law School Scholarship Repository. It has been accepted for inclusion in Articles by an authorized administrator of University of Michigan Law School Scholarship Repository. For more information, please contact mlaw.repository@umich.edu. 
What is the Practice of Medicine?-In a populár sense, and as ordinarily understood the practice of medicine is the applying of medical or surgical agencies for the purpose of preventing, relieving, or curing disease, or aiding natural functions, or modifying or removing the results of physical injury. Stez'art v. Raab, 55 Minn. 20, 56 N. W. Rep. 256. But in some relations, and for some purposes, the expression has a more extended meaning. This is to be found sometimes in statutory provisions, sometimes in the decisions of the courts upon questions involving the construction of the expression and sometimes in both. Medical acts not infrequently state what shall be deemed to be the practice of medicine under them. But even where this is so, the courts are often called upon to interpret the words of the legis- 
lature and to determine whether or not certain acts of a party make him a practitioner of medicine within the meaning of the governing statute. Where the medical act contains no direct provision in regard to the matter, the court: in case of litigation, must determine what is the practice of medicine, and in so doing must take into consideration the general scope and purpose of the statute. The medical statutes have been enacted primarily for the protection of the public, although incideritally the medical profession are protected by these laws. The difficult cases are not those where a person attempts to heal disease by the use of drugs or ordinary appliances, but rather those where resort is had to new-or extraordinary methods. Some of 'the ways in which this question has arisen appear in the following paragraphs.

In the recent case of State v. Yegge (S. Dak.), 103 N. W. Rep. ${ }_{7}, 69 \mathrm{~L}$. R. A. 504, it was contended that the defendant was practicing medicine in violation of the statute of the state which provided that "When a person shall append or prefix the letters 'M.B.' or 'M.D.,' or the title 'Dr.' or 'Doctor,' or any other sign or appellation in a medical sense, to his or her name, or shall profess publicly to be a physician or surgeon, or who shall prescribe or direct for the use of any person any drug, medicine, apparatus, or other agency for the cure, relief or palliation of any ailment or disease of the mind or body. or for the cure or relief of any wound, fracture, or bodily injury or deformity, after having received, or with the intent of receiving therefor, either directly or indirectly, any bonus, gift or compersation, he or she shall be regarded as practicing within the meaning of this act." It seems that the defendant was a practitioner of what he called "ophthalmology", that he advertised himself as such, and that he claimed in his advertisements that certain specific diseases could be cured by removing the causes through the use of his methods. $\mathrm{He}$ administered no drugs or medicines of any kind, but treated his patients simply by the fitting of glasses. His advertisements were signed "Dr. MI. F. Yegge." It was contended on the part of the defendant that the evidence was insufficient to warrant his conviction in that it failed to show that he was practicing or attempting to practice medicine within the prorisions of the act quoted, and that he was simply engaged in the business of fitting glasses to the eye. But the court held that it was not only clear from the language of the advertisement which was in evidence that it would be generally understood that he was holding himself out as a regular physician, or at least a specialist in the branch of medicine treating of ophthalmology, but that he was plainly within the statute by reason of having prefixed the term "Dr." to his name when signing his advertisements. "The legislature," says the court, "evidently intended in enacting the law fo prevent persons not properly educated in the science of medicine from assuming to act as physicians and to protect the public. $* * *$ The law should not be so construed as to deprive the people of the benefits. intended by the act, but such a construction should be given it as to carry into effect the evident intention of the legislature." A case, somewhat similar to the foregoing arose in the state of Illinois. where the medical act provides that any person shall be considered a medical practitioner within the meaning of the act, "who shall treat or profess to treat. operate on, or prescribe for any physical ailment or any physical injury to, or 
deformity of, another." Hurd's Ill. Stat. (1903) Chap. 9I, Sec. II In People v. Smith, 208 Ill. 3I, 69 N. E. Rep. 810, it was held that rene who travels from place to place fitting and selling spectacles, and who advertises himself as "The Famous Chicago Eye Expert," and inv: _- persons having the symptoms described to call upon him, but stating nat he does not give medical or surgical treatment, is not within the provisions of the medical act of the state.

Sometimes the statute regulating the practice of medicine provides that the statute shall only apply to those practicing for reward or compensation. State v. Paul, 56 Neb. 369,76 N. W. Rep. $86 \mathrm{r}$; State v. Pirlot, 20 R. I. 273 , 38 Atl. Rep. 656; State v. Hale, I5 Mo. 606; State v. Wilcox, 64 Kan. 789, 68 Pac. Rep. 634; Blalock v. State, II2 Ga. 338, 37 S. E. Rep. 361. In the absence of such a provision, one may be a practitioner within the meaning of the governing statute although he does not practice for compensation. State v. Welch, i29 N. C. 579,40 S. E. Rep. I20. But ordinarily it would not be held to be the practice of medicine to give advice or medicine to a sick person in a friendly or neighborly way, the person performing such services not holding himself out as a physician, or charging for his services. The legislature in the exercise of its police power might, perhaps, prohibit such friendly services, but in the absence of a direct prohibition in regard to the matter, the rendering of them would not ordinarily be the practice of medicine. Nelson v. State, 97 Ala. 79, 12 South. Rep. 42I. Gratuitous medical services rendered' in case of an emergency would not be the practice of medicine. Greenfield v. Gtlmait, 140 N. Y. 168, 35 N. E.. Rep. 435. An exception in regard to such services will be found in some of the medical acts. State v. Paul, 56 Neb. $369,76 \mathrm{~N}$. W. Rep. 86I. But in order that the emergency exception of a statute may apply, the emergency must be a real one; the situation must be such as to demand immediate medical aid in order that iife or health may not be endangered. People v. Lee Wah, 7 I Cal. 80, II Pac. Rep. 85 I.

Where it was provided in an act making it a misdemeanor to practice medicine without first having obtained a certificate of qualification from one of the authorized boards oi medical examiners, that the act should not apply "to any physician practicing medicine in this state for the past five years," it was held that the word "physician" was used in its popular sense, as one who practices medicine or the healing art, and that one who continued the practice of medicine for the time mentioned in the statute, although without a certificate of qualification, was within the proviso of the statute. Harrison v. State, 102 Ala. 170, 15 South. Rep. 563. But in this connection it should be noted that in Iowa the attitude of the Supreme Court upon a somewhat similar question is different. It is held by this court that a provision of the medical act of that state to the effect that a physician shall not by the act be prohibited from practicing if he has been in practice in the state for five consecutive years, three of which have been in one locality, provided satisfactory evidence of such practice be furnished the state board of examiners and a proper certificate secured from said board, does not give such physician a right to the certificate of the said board upon proof by him of the fact of his practice as provided in the statute. The court takes the position that the 
board in such a case may.pass uxpon the competency of the applicant to practice medicine, not because the act expressly provides that this may be done, but because such authority in the board is in accordance with the spirit and purpose of the law. State v. Mosher, 78 Ia. 32I, 43 N. W. Rep. 202.

Some of the medical statutes require special certificates for different departments of practice, but this is an exceptional provision. Usually the certificate from the state board in terms confers the right to practice medicine and surgery in the state, and this means to practice medicine and. surgery in any of their branches. But sometimes the act provides for the regulation of the "practice of medicine," and the certificate from the examining board authorizes the holder "to practice medicine" in the state. The term "practice miedicine" as so used has been held to signify the practice of medicine in all of its branches, including surgery. Steart v. Raab, 55 Minn. 20, 56 N. W. Rep. 256.

A question that has of late frequently challenged the attention of the courts is whether or not the practice of osteopathy as a profession and means of livelihood, is the practice of medicine within the provisions of the medical acts, Each case, of course, has necessarily been considered with reference to the language of the medical act in force where it arose. An examination of the acts and decided cases, however, will disclose the fact that similar language in different statutes has been difierently construed by the courts of last resort. This subject was fully considered in I MrCF. LA REV. 309, where all of the cases that had come before the courts of last resort up to the time of the writing of the note were reviewed. See also 2 Mich. LAw REv. 5I for a supplemental note upon the subject. It may be suggested here that osteopathy has been held to be the practice of medicine within the medical acts of Alabama, Nebraska and Illinois. 'The Ohio act of 1896 provided that "Any person shall be regarded as practicing medicine within the meaning of this act who shall *** for a fee, prescribe, direct, or recommend for the use of any person any drug, or medicine, or other agency for the treatment, cure, or relief of any wound, fracture, or bodily injury, infirmity, or disease." In State v. Liffring, 6I Ohio St. 39, the Supreme Court of the state held that osteopathy was not an "agency" within the meaning of the act. The reasoning upon which this conclusion was based was that the meaning of the word "agency" was limited by the associated words "drug" and "medicine," and that nothing could be regarded as an "agency" as the word was used in the act, that did not partake in some way of the general character of a drug or medicine, and that could not be applied or administered as drugs or medicines usually are. After the decision in this case, the Ohio statute was amended so as to include within its operation those "who shall prescribe, or who shall recommend, for a fee for like use, any drug or medicine, appliance, application, operation, or treatment, of whatever nature, for the cure or relief of any wound, fracture, or bodily injury, infirmity, or disease." 94 Ohio Laws (1900) 197-201. The statute as amended has been construed by the Supreme Court of the state to include the practice of osteopathy. State v. Gravett, 65 Ohio St. 289. In Kentucky the Supreme Court regards the practitioner of osteopathy as on the nlane of the trained nurse and as not within 
the provisions of the statute. Nelson v. State Board of Health, $68 \mathrm{Ky} .769$, 57 S. W. Rep. 50I, 50 L. R. A. 383 .

The legislature of North Carolina in 1903 amended the medical act of the state by passing a law defining the "practice of medicine and surgery." It is in the following terms: "For the purposes of this act the expression 'practice of medicine and surgery' shall be construed to mean the management, for fee or reward, of any case of disease, physical or mental, real or imaginary, with or without drugs, surgical operation, surgical or mechanical appliances, or by any other method whatsoever: Provided, that this shall not apply to midwives nor to nurses; Provided further, that applicants not belonging to -a regular school 'of medicine shall not. be requirec to stand an examination except upon the branches taught in their respective colleges (such branches being given in the act) ; Provided, that this act shall not apply to any person who ministers to or cures the sick or suffering by prayer to Almighty God without the use of any drug or material means."

In State v. Biggs, 133 N. C. 729,46 S. E. Rep. 401,64 L. R. A. ${ }^{1} 39$, the defendant was indicted upon the charge of unlawfully and wilfully engaging in the practice of medicine and surgery for fee or reward without having obtained 'from the state board of medical examiners a license so to do. Upon the facts found in a special verdict, the court below adjudged the defendant guilty. It appeared that he advertised himself as a "nonmedical physician;" that he held himself out to the public to cure disease by a "system of drugless healing," and to treat "patients by said system without medicine;" that the acts that he was found to have performed were to administer massage baths and physical culture, to manipulate the muscles, bones, spine, etc., and to advise his patients as to.diet. He used no drugs in his treatment. The defendant admitted that he had no license from the state board and claimed no exemptions by virtue of the provisos in the act. It was found that he had treated patients since the passage of the act and had received compensation therefor. The defendant's acts undoubtedly brought him within the statutory provisions above quoted, but the Supreme Court found that he was not guilty, as the police power does not confer upon the legislature authority so to define the practice of medicine and surgery that it shall include "the management, for fee or reward, of any case of disease, physical or mental, real or imaginary, with or without drugs, surgical operation, surgical or mechanical appliances, or by any other method whatsoever." "The act," says the court, "means more than its friends probably" intended, for it says 'any case of disease, physical or mental, real or imaginary.' Is not a disease of the eye physical, and is not a disease of the ear, or of the teeth, or a headache, or a corn, physical? - Then every dentist and aurist and oculist is indictable unless he has also license from the state medical society as an M.Đ., as is also every corn doctor who relieves aching feet; and every peripatetic of stentorian lungs, on the court house square who banisites headaches, real or imaginary, by rubbing his hands over some credulous brow. * * * Then there is the closing expression, forbidding treatment 'for fee or reward,' by other than an M.D., 'by any other method whatsoever.' This would take in all the old women and the herb doctors, who', without pre- 
tending to be professional nurses, relieve much human suffering, real or imaginary, for a small compensation. Then it is forbidden to relieve a case of suffering, physical or mental, in any method unless one is an M.D. It is not even admissible to 'minister to a mind diseased' in any method, or even dissipate an attack of the blues. without that label duly certified. $* * *$ The act is too sweeping. Besides, the legislature could no more enact that 'the practice of medicine and surgery' shall mean 'practice without medicine and surgery,' than it could provide that 'two and two make five,' because it cannot change a physical fact. And when it forbade all treatment of all diseases, mental or physical, without surgery or medicine, or by any other method, for a fee or reward, except by an M.D., it attempted to confer a monopoly on that method of treatment, and this is forbidden by the constitution."

This legislation is, perhaps, subject to some of the criticisms made upon it by the court in this case, and possibly the conclusion reached by the court as to the constitutionality of the act is correct, though it may be said in passing that the language of the judge writing the opinion is hardly judicial in charucter. Two members of the court concur. in the result reached, probably for the reason that they do not countenance the language used in the opinion. The North Carolina court, as indicated by the holding in this case, is evidently not $\mathrm{ln}$ sympathy with the notion that medical legislation should be so comprehensive in its range that ${ }_{1}$ none can properly practice medicine in any of its forms excepting those who have been thoroughly trained so to do. In the opinion of this court, such legislation should be confined to provisions in regard to the admission to some branch of the regular medical profession. The court says: "The public have the right to know that those holding themselves out as members of that ancient and honorable profession are competent and duly licensed as such. The legislature can exercise its police power to that end because it is a profession whose practice requires the highest skill and learning. But there are methods of treatment which do not require much skill and learning, if any. Patients have the right to use such methods if they wish, and the attempt to require an examination of the character above recited for the application of such treatment is not warranted by any legitimate exercise of the police power. The effect would be to prohibit to those who wish it, those cheap and simple remedies, and deprive those who practice them of their humble gains, by either giving a monopoly of such remedies to those who have the title M.D., or prohibiting the use of such remedies altogether, neither of which results the legislature could have contemplated." It may be suggested that so narrow a construction of the police power in connection with medical legislation would result in very little protection to the public from designing quacks and pretenders. A statute similar to that of North Carolina, above quoted, has been upheld by the Supreme Court of New Mexico. Territory of Neze Mexico v. Nezman, (N. M.), 79 Pac. Rep. 706, 813, 68 L. R. A. 783 .

The practice of Christian science, so-called, has been held by the Supreme Court of Rhode Island not to be the practice of medicine within the provisions of the medical act of the state. State ex rel Swarts v. Mylod, zo R. I. 
632, 40 Atl. Rep. 753, 4I I. R. A. 428. But in Nebraska one who practices Christian science has been held to be subject to the medical act of the state. State v. Buszeell, $40 \mathrm{Neb}$. 158 . The medical act of Illinois coritains an express provision that it shall not apply to "any person who ministers. to, or treats, the sick or suffering, by mental or spiritual means without the use of any drug or material remedy." Hurd's Ill. Stat. (rg03) Chap. 9i, Sec. II.

A magnetic healer who advertised himself as such and styled himself "professor" has been held to be subject to the restrictions of the statute requiring a license of persons who announce to the public a readiness to cure disease, or who in connection with their names use the word "professor," or any other title, intending thereby to designate themselves as practitioners of medicine in any of its branches: Parks v. State, I59 Ind.. 2I I, 64 N. E. Rep. 862,59 I. R. A. igo. And a medical clairvoyant has been held to be a practitioner of medicine within the provisions of the statute making the recovery of compensation for medical or surgical services dependent upon a compliance with a statute in regard to professional attainments, moral character, etc. Bibber v. Simpson, $59 \mathrm{Me}$. I81. But it has been held that a peison who recommends and offers for sale an instrument or appliance to be attached to the body for the cure of disease is riot practicing medicine within the meaning of the provision of the Illinois act hereinbefore quoted. People v. Lehr, Ig6 Ill. $36 \mathrm{I}, 63$ N. E. Rep. 725. The vendor of proprietary medicines who simply sells the medicines and does not attempt to diagnose disease and prescribe his remedy, is not a practitioner of medicine, yet he may become such by holding himself out as a physician and varying his prescriptions of proprietary remedies, to meet the symptoms discovered by him on his own examination. State v. Van Doran, Iog N. C. $864,870,871$, I4 S. E. Rep. 32; Payjie y. State, II2 Tenn. 587, 79 S. W. Rep. I025; Regina -v. Howarth, 24 Ont. 56I. If in selling proprietary medicines the vendor distinctly declares that he is not a physician, and receives pay simply for the medicine, he could not be held to be a medical practitioner, even though he gives advice as to the use of. his medicine. Conimonwealth v. St. Pierre, 175 Mass. 48, 55 N: E. Rep. 482 .

It may properly be suggested that the medical laws as a rule are framed with a view of reaching conditions existing at the time of their enactment, and that they are often ineffective because of a failure to proyide by comprehensive language for changed conditions. By reason of this fact, as an examination of the statutes and decided cases will show, the ignorant and designing pretender who is foisting upon the public some new but worthless. and perhaps harmful treatment is not infrequently beyond the reach of the law. . 